University of Nebraska - Lincoln

DigitalCommons@University of Nebraska - Lincoln

\title{
Synchronous climatic change inferred from diatom records in four western Montana lakes in the U.S. Rocky Mountains
}

\author{
Brandi Bracht-Flyr \\ University of Nebraska-Lincoln, brachtflyr@huskers.unl.edu \\ Sherilyn C. Fritz \\ University of Nebraska-Lincoln, sfritz2@unl.edu
}

Follow this and additional works at: https://digitalcommons.unl.edu/geosciencefacpub

\footnotetext{
Bracht-Flyr, Brandi and Fritz, Sherilyn C., "Synchronous climatic change inferred from diatom records in four western Montana lakes in the U.S. Rocky Mountains" (2012). Papers in the Earth and Atmospheric Sciences. 390.

https://digitalcommons.unl.edu/geosciencefacpub/390
}

This Article is brought to you for free and open access by the Earth and Atmospheric Sciences, Department of at DigitalCommons@University of Nebraska - Lincoln. It has been accepted for inclusion in Papers in the Earth and Atmospheric Sciences by an authorized administrator of DigitalCommons@University of Nebraska - Lincoln. 


\title{
Synchronous climatic change inferred from diatom records in four western Montana lakes in the U.S. Rocky Mountains
}

\author{
Brandi Bracht-Flyr ${ }^{1}$ and Sherilyn C. Fritz ${ }^{1,2}$ \\ 1. Department of Earth and Atmospheric Sciences, University of Nebraska-Lincoln, Lincoln, NE, 68588-0340, USA \\ 2. School of Biological Sciences, University of Nebraska-Lincoln, Lincoln, NE, 68588-0340, USA \\ Corresponding author — S. C. Fritz; Emails: brachtflyr@huskers.unl.edu \& sfritz2@unl.edu
}

\begin{abstract}
Late-Holocene environmental and climatic conditions were reconstructed from diatom assemblages in sediment cores from four western Montana lakes: Crevice Lake, Foy Lake, Morrison Lake, and Reservoir Lake. The lakes show synchroneity in timing of shifts in diatom community structure, but the nature of these changes differs among the lakes. Two of the sites provide highly resolved records of hydrologic balance, while the other two stratigraphic sequences primarily record temperature impact on lake thermal structure. All four lakes show significant change in five discrete intervals: $2200-2100,1700-1600,1350-1200,800-600$, and 250 cal yr BP. The similarities in the timing of change suggest overlying regional climatic influences on lake dynamics. The 800-600 cal yr BP shift is evident in other paleorecords throughout the Great Plains and western US, associated with the transition from the Medieval Climate Anomaly to the Little Ice Age. Large-scale climatic mechanisms that influence these lake environments may result from atmospheric circulation patterns that are driven by interactions between Pacific and Atlantic sea-surface temperatures, which are then locally modified by topography.
\end{abstract}

Keywords: diatom, lake-level, paleoclimate, Holocene, western North America, Little Ice Age, Medieval Climate Anomaly

\section{Introduction}

The importance of the northern Rocky Mountains in the hydrologic system of western North America has led to many recent studies to quantify the nature and timing of past climate variation, particularly of drought (Buntgen et al., 2005; Stone and Fritz, 2006; Cook et al., 2007; Gray et al., 2007). It is difficult to characterize regional patterns of past climatic variability in this area, because mountains modify large-scale atmospheric circulation via various mechanisms (Williams et al., 1996), including channelization of winds, rain-shadow effects, and glacier influences (Barry, 1990). As a result, sites separated by only a few kilometers may experience significantly different local climate, including differences in temperature, precipitation, and winds (Barry, 1992). The spatial heterogeneity of climate in montane regions raises doubt about the accuracy or usefulness of single-site paleorecords in portraying a coherent representation of regional climate.

At present, relatively few high-resolution paleoclimatic records that span the past $2500 \mathrm{yr}$ are available for the northern Rocky Mountain region. Thus, the degree of spatial heterogeneity of past climate within the region is not yet defined. Tree-ring records are relatively abundant, but the shorter time scales, which span only the last several hundred years to the last millennium, may not capture the full range of regional climatic variability that is characteristic at multi-decadal to centennial scales (Briffa et al., 2001; Gray et al., 2004; Salzer and Kipfmueller, 2005).
Here we use changes in diatom assemblage composition to reconstruct and compare patterns of environmental variation at four western Montana lakes in the northern tier of the US Rocky Mountains: Crevice Lake, Foy Lake, Morrison Lake, and Reservoir Lake. The lakes are within close geographic proximity to one another (within $~ 400 \mathrm{~km}$ ); however, they vary in their elevation (Table 1), vegetation, and overall geomorphic setting. Two of the lakes are sufficiently remote that site-specific climatological data are not available, but the differences in their elevation and topography, relative to the other two sites, have the potential to produce significant differences in local climate, as reflected by the differences in the composition and cover of the contemporary conifer forests that surround the lakes. Within western Montana, precipitation seasonality is particularly variable in that some sites receive considerable monsoonal precipitation in summer, whereas in other areas the majority of precipitation falls in winter months (Whitlock and Bartlein, 1993) (Figure 1b). The summer precipitation originates in the Gulf of Mexico and is transported into parts of the region via low topographic corridors.

In this paper, we explore the extent to which these montane lakes have undergone similar patterns of limnological and inferred climate variation in the past $\sim 2500 \mathrm{yr}$. Diatoms are used to reconstruct past limnological and climatic history, including patterns of lake stratification associated with temperature variation in spring and summer, as well as changes in lake chemistry and depth driven by effective moisture. We apply several different statistical methods to the diatom 
Table 1. Limnologic and geographic characteristics of each lake. Lat $(\mathrm{N})$ is latitude, Long (W) is longitude, Elev (m) is elevation, SA $\left(\mathrm{km}^{2}\right)$ is surface area, TP $(\mathrm{mg} / \mathrm{L})$ is total phosphorus, TN $(\mathrm{mg} / \mathrm{L})$ is total nitrogen, Sec $(\mathrm{m})$ is Secchi depth, and Con $(\mu \mathrm{S} / \mathrm{cm})$ is conductivity. Geochemical sampling or analysis occurred during the summer months of 2002 for Foy Lake and 2007 for Crevice, Morrison, and Reservoir Lakes.

\begin{tabular}{llllllllll}
\hline Lake & Lat & Long & Elev & SA & TP & TN & Sec & pH & Con \\
\hline Crevice & $45^{\circ} 0^{\prime} \mathrm{N}$ & $110^{\circ} 36^{\prime} \mathrm{W}$ & 1713 & 0.1 & 0.03 & 0.47 & 7.0 & 8.5 & 600 \\
Foy & $48^{\circ} 10^{\prime} \mathrm{N}$ & $114^{\circ} 21^{\prime} \mathrm{W}$ & 1006 & 0.9 & - & - & 7.0 & 7.5 & 1090 \\
Morrison & $44^{\circ} 36^{\prime} \mathrm{N}$ & $113^{\circ} 2^{\prime} \mathrm{W}$ & 2490 & 0.1 & 0.02 & 0.75 & 7.0 & 8.8 & 220 \\
Reservoir & $45^{\circ} 7^{\prime} \mathrm{N}$ & $113^{\circ} 27^{\prime} \mathrm{W}$ & 2155 & 0.2 & 0.04 & 0.41 & 7.0 & 8.3 & 20 \\
\hline
\end{tabular}

stratigraphies to determine if the nature and timing of changes in the diatom community structure are similar among the lakes and therefore to evaluate whether or not the variation is likely a direct response to regional environmental forcing related to climate.

\section{Environmental setting}

All four lakes are located within the northern Rocky Mountains of western Montana, U.S.A. (Figure 1). Crevice Lake is located within Yellowstone National Park, Foy Lake is in the Salish Mountains, and both Reservoir and Morrison lakes are within the Beaverhead Mountains. The lakes are all sub-alpine, alkaline in $\mathrm{pH}$, and mesotrophic to eutrophic (Table 1). The Crevice Lake basin is dominated by mixed conifer and sagebrush vegetation. Common species include Pseudotsuga menziesii, Juniperus scopulorum, Pinus flexilis, and Artemisia tridentata. Around the lake, Betula occidentalis, Alnus incana, and Salix are common, with Carex, Scirpus, and Typha latifolia around the lake margin. Vegetation within the Foy Lake basin is closed conifer forest of $P$. menziesii, Pinus ponderosa, Larix occidentalis, J. scopulorum, and Pinus contorta forest (Power et al., 2006). Morrison Lake is surrounded by P. contorta. The Reservoir Lake ba$\sin$ is open mixed conifer forest that includes P. menziesii, P. contorta, A. tridentata, and Poaceae (Gage, 2008). The southern edge of the lake contains abundant Nuphar and Scirpus.

Crevice, Reservoir, and Morrison lakes are small, remote, topographically closed-basin lakes that vary in elevation from 1000 to $2500 \mathrm{~m}$. Foy Lake is the largest and lowest elevation of the four lakes (Table 1), with significant human development surrounding the lake and an intermittent outlet. All the lakes likely result from glacial activity that carved out deep depressions, and all the lakes are situated in glacial till. Each of the lakes is at least $15 \mathrm{~m}$ deep (Figure 2). The water depth in all lakes is conducive to seasonal or yearly anoxia, which aids in preservation of sedimentary structures and laminations. Crevice and Foy lakes contain annually laminated sediments (varves), which are organic-carbonate couplets (Stevens et al., 2006; Whitlock et al., 2008). All the available limnological data are summarized in Table 1.

\section{Climatic setting}

Western Montana is characterized by an alpine-continental climate with cold winters and moderate summers (Mock, 1996). Precipitation amount and seasonality are spatially variable within the region as a result of the variable topography (Whitlock and Bartlein, 1993). Western Montana climate is heavily influenced by the strength and position of the North American polar jet stream, which commonly traverses these latitudes during winter months, and all sites receive substantive winter precipitation originating from the Pacific (Whitlock and Bartlein, 1993). In many areas, the summer and fall seasons are dry, which reflects the influence of the eastern Pacific sub-tropical high-pressure system, which produces large-scale regional subsidence. However, some locations receive significant summer precipitation from the Gulf of Mexico, which is channeled into the interior along low-elevation corridors. Areas that receive this monsoonal precipitation commonly have a precipitation maximum in summer months: http://www.esrl.noaa.gov/ psd/data/usclimdivs/data/map.html

Crevice Lake is the eastern-most site (Table 1), Foy Lake is farthest to the north and west, and both Morrison Lake and Reservoir Lake are within the southwestern portion of the region. Two climate monitoring stations are located within $8 \mathrm{~km}$ of Crevice Lake: Mammoth Hot Springs, WY (1901 m) and Gardiner, MT $(1619 \mathrm{~m})$. The two sites vary considerably in precipitation, receiving $393.7 \mathrm{~mm} / \mathrm{yr}$ and $236.9 \mathrm{~mm} / \mathrm{yr}$, respectively ( http://www. ncdc.noaa.gov ), a contrast that reflects the elevational differences. The northern portion of Yellowstone National Park (YNP), where Crevice is located, receives significant precipitation during summer months (Figure 1b) (Whitlock et al., 2008). Climatological data from Kalispell, Montana ( http://www.ncdc.noaa.gov ), located $4.8 \mathrm{~km}$ from Foy Lake, which is located in the Flathead Valley, shows that the site receives the majority of its precipitation during May and June (Stevens et al., 2006), whereas the precipitation maxima in many neighboring areas occur during October-March (Figure 1). These differences reflect elevation gradients, such that lowelevation sites, including Foy Lake, receive considerable summer precipitation. Weather station data from Kalispell report an average precipitation of $381 \mathrm{~mm} / \mathrm{yr}$ and an average annual temperature of $6.1^{\circ} \mathrm{C}$. Morrison and Reservoir lakes are extremely remote, without nearby meteorological stations to infer local climatological trends. Some of the region near Morrison Lake receives significant summer precipitation (Figure 1), but whether or not this is true at the elevations of the lake $(2490 \mathrm{~m})$ is unclear. In the vicinity of Reservoir Lake $(2490 \mathrm{~m})$, wintertime precipitation exceeds that of summer, although the lake is near the eastern margin of this zone (Figure 1).

\section{Methods}

\section{Coring}

Multiple sediment cores were recovered from the ice surfaces of Crevice, Reservoir, Morrison, and Foy lakes, using freeze cores to retrieve the surface mud (except for Morrison) combined with either Austrian or Livingston cores for the underlying sediments. Crevice Lake was cored during 2001, Foy Lake in 2000 and 2002, Reservoir Lake during 1996, and Morrison Lake during 2000. The freeze and piston cores were combined into a single continuous sequence based upon overlapping sedimentological features. The cores from Crevice and Foy lakes contain varves, which are organic-carbonate couplets that are useful in age model development. Lake cores were sub-sampled at 2-4 mm intervals for Crevice Lake, 1-cm intervals for Reservoir Lake, $0.5 \mathrm{~cm}$ intervals for Morrison Lake, and by annual varves for Foy Lake (Stevens et al., 2006). Each sample was homogenized before sub-sampling.

\section{Diatoms}

Diatom subsamples were treated with cold hydrochloric acid and hydrogen peroxide to digest the carbonate and organic material, respectively. Rinsed samples were dried onto coverslips and mounted onto slides with a permanent mounting medium (Battarbee and Kneen, 1982). At least 300 diatom valves were counted per slide, with the exception of Morrison Lake. The extreme dissolution of diatoms in some portions of the Morrison Lake core prevented a count of 300 diatom valves for many samples.

\section{Age models}

The development and robustness of the four age models differ among lakes, based on the availability of counted varves or dateable material. The Crevice Lake age model was developed using both AMS ${ }^{14} \mathrm{C}$ dates and varves (Whitlock et al., 2008). The Foy Lake chronology was developed using varve counts and $\mathrm{AMS}{ }^{14} \mathrm{C}$ dates (Stevens et al., 2006). Morrison Lake has two ${ }^{14} \mathrm{C}$ dates and the top 
a

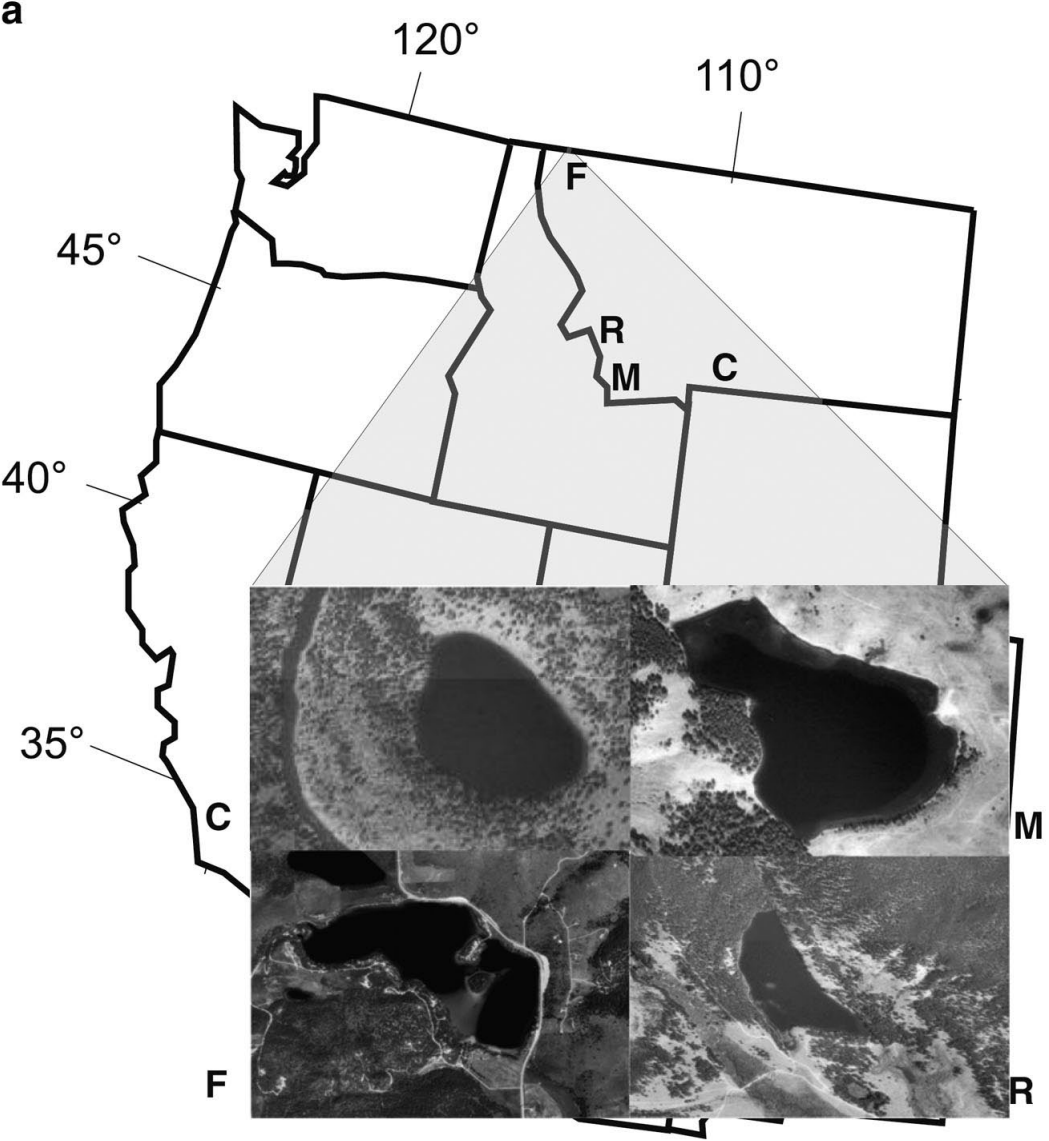

b PRISM 2.5-min Data July/January Precipitation Ratio

Figure 1. a. The location of the four lakes included in this study, Crevice Lake (C), Foy Lake (F), Morrison Lake (M), and Reservoir Lake (R). b. The seasonal distribution of precipitation in western Montana and adjoining states, expressed as a ratio of July to January precipitation for the period 1971-2000. Areas in green receive the majority of their precipitation in summer months. Data are from PRISM Group, Oregon State University, http://www.prismclimate. $\underline{\text { edu }}$

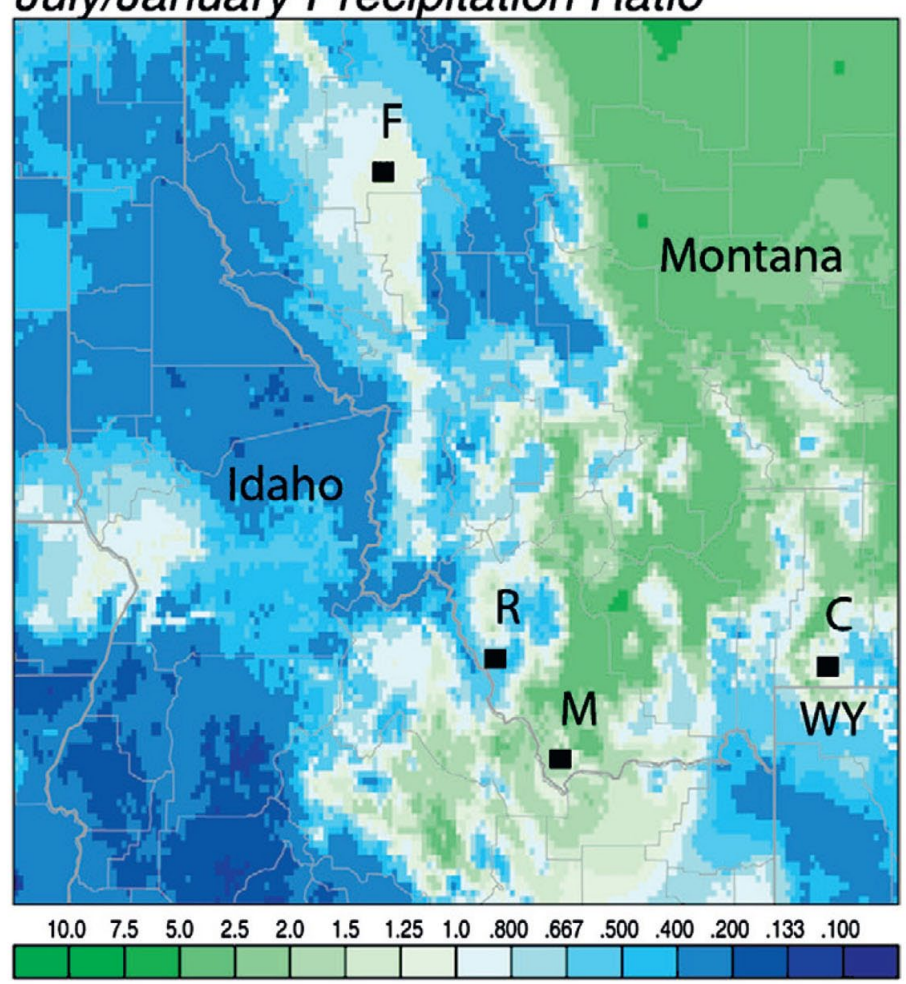

PRISM Data: OSU SCAS [http://www.ocs.orst.edu/prism/] Maps \& Data Analysis: Dept Geography, Univ. Oregon [http://geography.uoregon.edu/envchange/] 


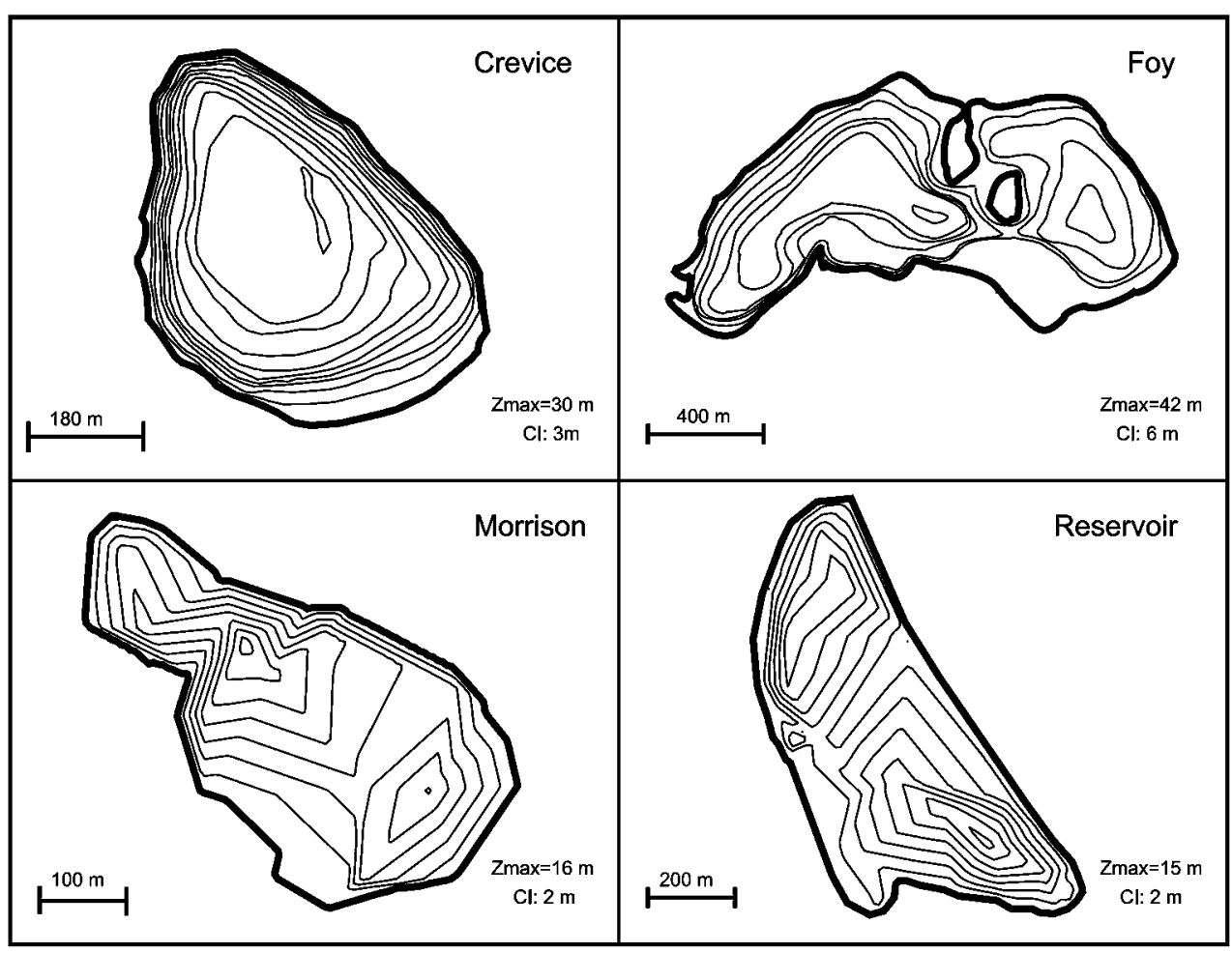

Figure 2. Bathymetric maps of the four lakes. The Crevice Lake bathymetric map is from the Yellowstone National Park Service; the Foy Lake map is from Stone and Fritz (2004). The Morrison Lake and Reservoir Lake maps are from measurements made during the 2007 field season, which were then gridded using Surfer. CI refers to the contour interval used in delimiting bathymetry, and $\mathrm{Z}_{\max }$ refers to maximum lake depth, which is where each core was taken.

of the core to constrain the age model (Table 2). Despite the limited number of ${ }^{14} \mathrm{C}$ dates, the relatively homogenous character of the sediments does not suggest major changes in sedimentation pattern or rate during the period analyzed. Core chronology for Reservoir Lake uses both ${ }^{210} \mathrm{~Pb}$ dating of the freeze core and ${ }^{14} \mathrm{C}$ dating of charcoal and macrofossils in the long core (Table 2). The Reservoir Lake model developed by Gage (2008) utilized the spline-based modeling procedure of Higuera et al. (2007). One of Reservoir Lake's ${ }^{14} \mathrm{C}$ dates was not used in the age model as it was thought to contain reworked material (Gage, 2008). All radiocarbon dates were calibrated to calendar years using Calib 5.2 (Stuvier et al., 1993).

\section{Data analysis and statistical techniques}

Several techniques were employed to evaluate the coherence in timing and direction of change among the four lake-core records. First, we plotted the species percent abundances through time to describe significant changes in diatom community structure. A zonation scheme was then developed for each lake with stratigraphically constrained cluster analysis on square-root transformed data, chord distance measure, using CONISS (Constrained Incremental Sums of Squares cluster analysis) (Grimm, 1987) and Psimpoll 4.10 (Bennett, 1996). In addition to visual comparisons of zonation schemes, detrended correspondence analysis (DCA) using Canoco 4.5 (ter Braak and Smilauer, 2002) and spectral analysis were performed on the diatom data. Each DCA was run on both the entire species dataset and a dataset containing only the species that achieved at least 5\% abundance. The 5\% DCA component scores were then re-sampled using AnalySeries to obtain the constant sampling interval necessary for spectral analysis (Paillard et al., 1996). The re-sampled datasets were then run with the SSAMTM Toolkit multi-taper method for spectral analysis (Ghil et al., 2002). Although chronological control for Morrison Lake is limited to two ${ }^{14} \mathrm{C}$ dates, there is no clear evidence for changes in sedimentation rate that might affect the age model, and we chose to retain it in the spectral analysis, recognizing the potential limitation of the age model.

\section{Results}

\section{Lithology and geochemistry}

The Crevice Lake core consists of light-brown laminated gyttja with some sulfide mineral nodules. Fine couplets of calcareous silty clay or clay silt alternating with calcite, approximately $0.3 \mathrm{~mm}$ thick, are interpreted as varves based upon comparison with ${ }^{14} \mathrm{C}$ ages (Whitlock et al., 2008). Foy Lake, during the interval considered, consists of finely laminated red and green gyttja, with a highly carbonaceous zone (18-31 cm) (Stevens et al., 2006). The fine organic/carbonate couplets are interpreted as varves. The Morrison and Reservoir Lake cores both consist of light-brown, organic-rich sediments (gyttja).

\section{Age models}

Polynomials were fitted to the Crevice and Foy Lake age-depth data, using the same age models as in prior publications (Stevens et al., 2006; Whitlock et al., 2008) (Figure 3). Linear interpolation of radiocarbon dates was used to generate the chronology for Morrison Lake, while a splined based modeling procedure was used for the Reservoir Lake chronology, which incorporates both ${ }^{14} \mathrm{C}$ and ${ }^{210} \mathrm{~Pb}$ dates (Figure 3 ).

\section{Limnological histories}

The diatom records of the four lakes exhibit a range of compositional shifts that can be interpreted as limnological responses to environmental changes. Crevice Lake has four main units based on 
Table 2. Materials used for development of the age models for Morrison and Reservoir Lakes. The Foy Lake age model is described in Stevens et al. (2006), while the Crevice model is in Whitlock et al. (2008). Depths are measured from the sediment-water interface. For Reservoir Lake, the analyzed sequence included bulk sediment samples from a $210 \mathrm{~Pb}$ dated freeze core, which was combined with a Livingstone piston core sequence that was dated by radiocarbon analyses (see text). Median ages are in cal yr BP (prior to 1950).

\begin{tabular}{|c|c|c|c|c|c|c|}
\hline Lake & Sample & Material & $\begin{array}{l}\text { Depth } \\
(\mathrm{cm})\end{array}$ & $\begin{array}{l}{ }^{14} \mathrm{C} \\
\text { age }\end{array}$ & $\mathrm{Cal} 2 \sigma$ & $\begin{array}{r}\text { Med } \\
\text { age }\end{array}$ \\
\hline Morrison & - & Twig & 14 & 170 & $142-218$ & 187 \\
\hline Morrison & - & Wood & 115 & 2980 & $3101-3240$ & 3171 \\
\hline Reservoir & - & Bulk Sediment & 0 & - & - & -46 \\
\hline Reservoir & - & Bulk Sediment & 27 & - & - & -26 \\
\hline Reservoir & - & Bulk Sediment & 51 & - & - & 44 \\
\hline Reservoir & CAMS-118868 & Needle & 226 & 1340 & $1179-1310$ & 1275 \\
\hline Reservoir & CAMS-118867 & Needle/Charcoal & 299 & 2095 & $1952-2152$ & 2067 \\
\hline Reservoir & CAMS-116257 & Needle & 357 & 2545 & $2496-2748$ & 2631 \\
\hline
\end{tabular}

differences in diatom community structure (Figure 4). From 2550 to $2100 \mathrm{cal} \mathrm{yr} \mathrm{BP,} \mathrm{the} \mathrm{lake} \mathrm{is} \mathrm{dominated} \mathrm{by} \mathrm{two} \mathrm{planktonic} \mathrm{species,}$ Stephanodiscus minutulus, a high phosphorus (P) specialist, and Synedra tenera (a low P specialist). Neither species does well under low nitrogen $(\mathrm{N})$ availability. S. minutulus blooms during times of prolonged spring mixing, when $\mathrm{P}$ is mixed throughout the water column, whereas $S$. tenera grows later in the season when P concentrations are lower ( Bradbury, 1988; Kilham et al., 1996; Interlandi et al., 1999; Bracht et al., 2008). In contemporary lakes within the Yellowstone region, $S$. tenera increases in relative abundance after $S$. minutulus blooms, but prior to the onset of stratification. Thus, the co-dominance of these species in the sediments may be indicative of years of particularly long periods of isothermal mixing in spring to early summer ( Bradbury, 1988; Interlandi et al., 1999; Morabito et al., 2001). From 2100 to $800 \mathrm{cal} \mathrm{yr} \mathrm{BP,} \mathrm{the} \mathrm{diatom} \mathrm{assemblage} \mathrm{shifts}$ to a Cyclotella-dominated community. The two dominant taxa, $C y$ clotella bodanica and Cyclotella michiganiana, are summer taxa that thrive under low $\mathrm{N}$ levels and in well-stratified water columns (Interlandi et al., 1999). The high relative abundance of these two species suggests long summers that were sufficiently warm to produce persistent lake stratification. The period from $800 \mathrm{cal} \mathrm{yr} \mathrm{BP} \mathrm{to} \mathrm{pres-}$ ent is dominated by $S$. minutulus, with a short interval dominated by $C$. bodanica. This suggests that most of this period had longer, cooler springs that prolonged water-column mixing, whereas the short interval (from $\sim 350$ to $\sim 150 \mathrm{cal} \mathrm{yr} \mathrm{BP}$ ) was characterized by truncated spring mixing and intensified summer stratification (when C. bodanica dominates).

Morrison Lake has a highly variable diatom stratigraphy, with frequent alternations among the diatom taxa. Two major diatom assemblages dominate throughout the 3250-yr record (Figure 5). The planktic genera Cyclotella and Stephanodiscus dominate from 3250 to $1150 \mathrm{cal} \mathrm{yr} \mathrm{BP}$ and 600 to $0 \mathrm{cal} \mathrm{yr} \mathrm{BP.} \mathrm{Multiple} \mathrm{alternations}$ from Stephanodiscus to Cyclotella, such as those at 2150,600, and $300 \mathrm{cal}$ yr BP, occur during these intervals. Shifts in dominance of these two planktic genera imply fluctuations in the relative length of the spring and summer seasons, similar to the controls described for Crevice Lake. From 1150 to $600 \mathrm{cal} \mathrm{yr} \mathrm{BP,} \mathrm{a} \mathrm{distinct} \mathrm{appearance}$ and dominance of $A$. formosa suggests several possible ecological influences on diatom community structure. A. formosa is a high Si:P specialist (Tilman et al., 1982) and benefits from higher N:P ratios (Kilham et al., 1996). In addition, many recent studies (Schmidt et al., 2002; Wolfe et al., 2003; Saros et al., 2005) found that $A$. formosa increases or dominates during periods of $\mathrm{N}$ enrichment. This suggests that the interval from 1150 to $600 \mathrm{cal}$ yr BP was warmer than prior and subsequent periods, which likely elevated the $\mathrm{N}$ inputs from the catchment to the lake during snowmelt in the spring (Theriot et al., 1997).

Reservoir Lake consists of two sub-basins connected by a shelf. From 2500 to $1700 \mathrm{cal}$ yr BP, water level was quite low, as evidenced by several periods of diatom dissolution (2350-2330, 2170-2140, and 1910-1890 cal yr BP) and the predominance of Cyclotella stelligera. This taxon is a shallow water tychoplankton that does well in warm, stratified waters with low nutrient conditions (Ruhland et al., 2003) (Figure 6). Diatom dissolution sometimes occurs during intervals of lower lake levels that concentrate salts, which can produce increased alkalinity. The siliceous diatom valves dissolve more readily in higher alkalinity waters. From 1700 to $1390 \mathrm{cal} \mathrm{yr} \mathrm{BP,}$ Reservoir Lake shows several oscillations in community structure from C. stelligera to benthic species. The morphometry of Reservoir Lake suggests that at certain depths, increases in benthic species represent an increase in water depth, as an increase in water

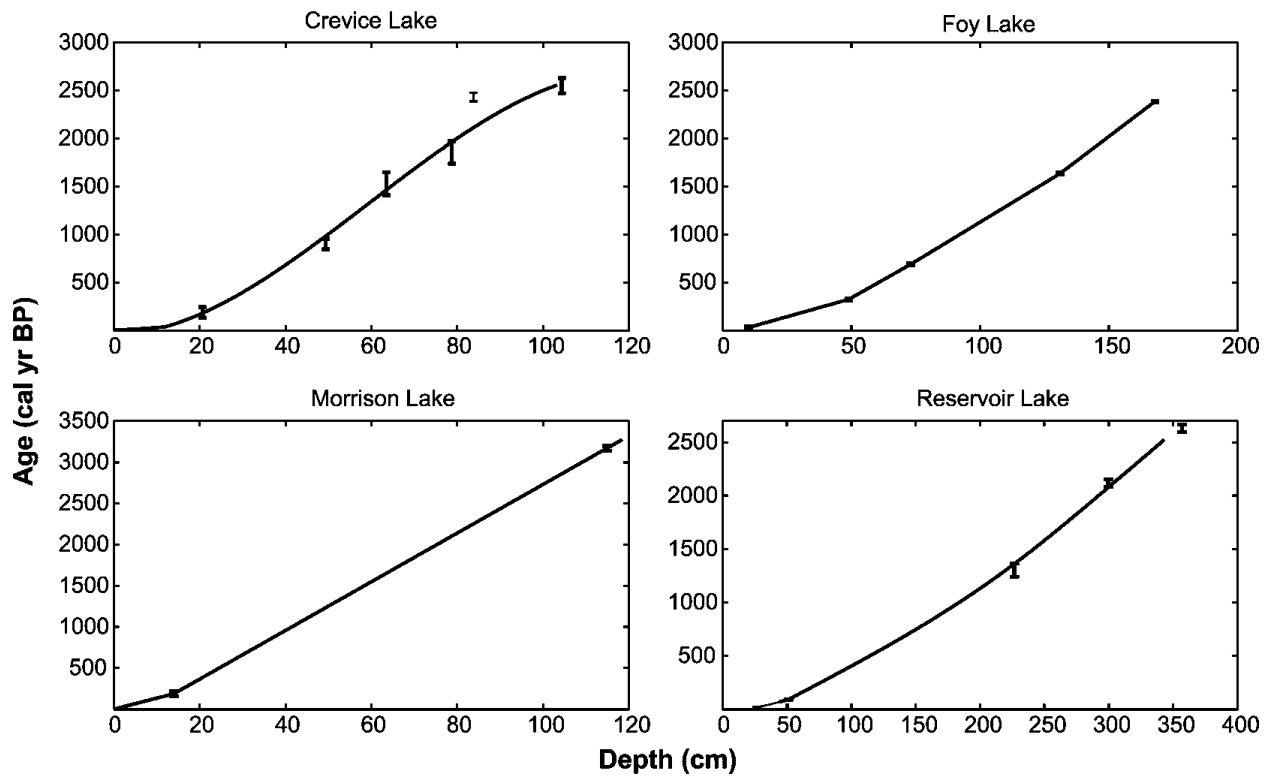

Figure 3. Age models for the four lakes. The Crevice Lake age model uses ${ }^{14} \mathrm{C}$ dates and varves (Whitlock et al., 2008). The Foy Lake age model contains ${ }^{14} \mathrm{C}$, ${ }^{210} \mathrm{~Pb}$, and varves (Stevens et al., 2006). The Reservoir Lake age model uses ${ }^{14} \mathrm{C}$ and ${ }^{210} \mathrm{~Pb}$ dates, whereas the Morrison Lake age model is based on the top of the core as 0 cal yr BP and two ${ }^{14} \mathrm{C}$ dates. See text and Table 1 for further details. 


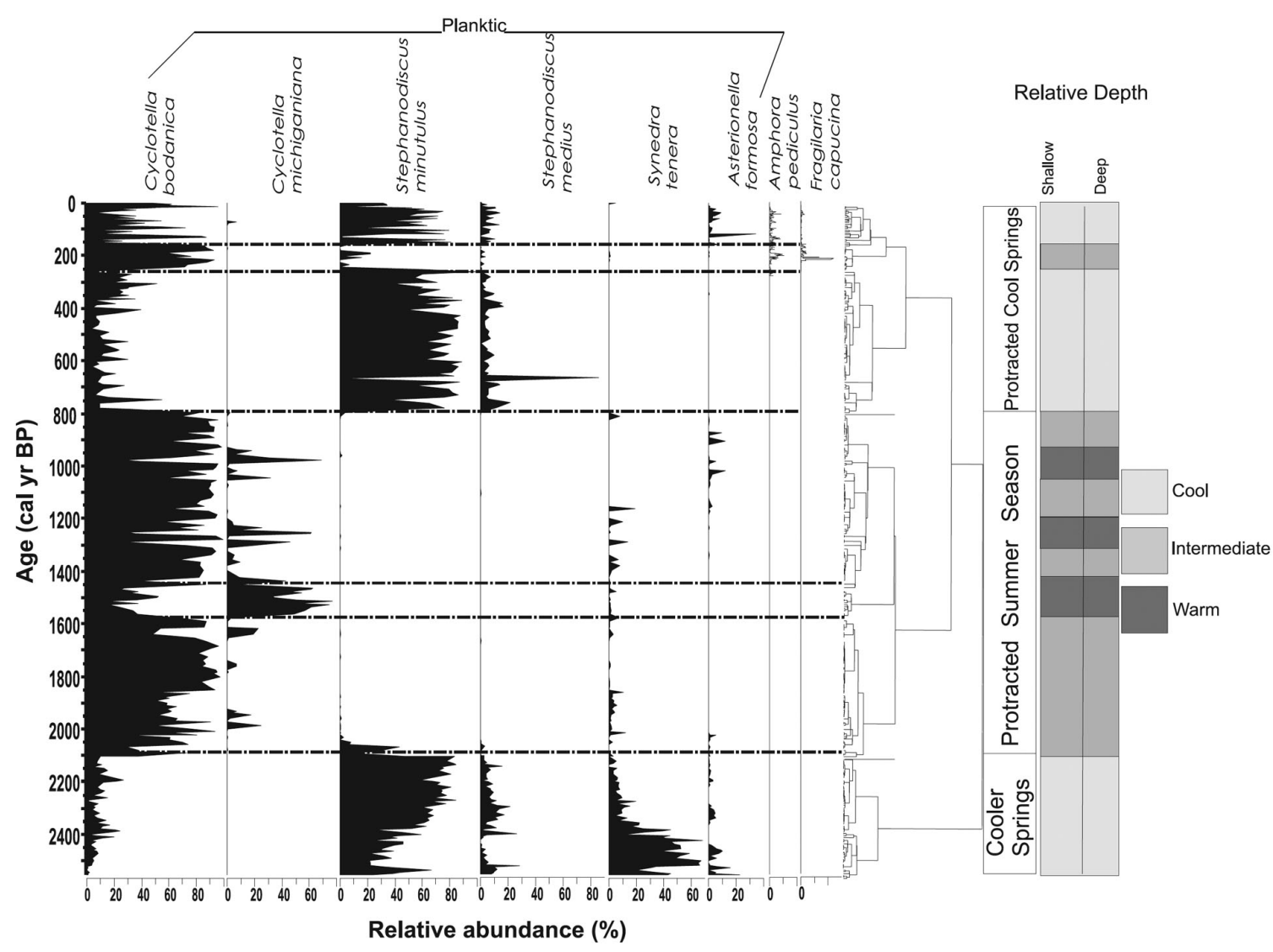

Figure 4. Crevice Lake diatom stratigraphy, cluster analysis, and climatic interpretation. The dashed lines are zones identified by cluster analysis. The schematic portion of the diagram shows a rough interpretation of the relative depth and relative temperature, based upon the diatoms. When Cyclotella bodanica and C. michiganiana are dominant, summer seasons are protracted and warmer, in comparison to the longer and cooler springs when Stephanodiscus minutulus is dominant. The Crevice Lake diatom record gives no indication of relative water depth, and therefore depth is represented by a flat line.

depth submerges a large shelf that connects the two smaller basins (Figure 2). Additionally, S. minutulus, a planktonic species, becomes co-dominant with increases in benthic species, further supporting the hypothesis that an increase in benthic species results from an increase, rather than decrease, in water depth. The intervals of $S$. minutulus dominance likely reflect years of high $\mathrm{P}$ availability because of extended spring mixing, as discussed previously.

In Reservoir Lake, the period from 1390 to $890 \mathrm{cal}$ yr BP shows a rapid rise and dominance of $A$. formosa, which may indicate an increase in $\mathrm{Si}: \mathrm{P}$ and $\mathrm{N}: \mathrm{P}$, as a result of increases in winter precipitation and runoff that elevates nitrogen and silica inputs (Theriot et al., 1997). A high N:P ratio is also fostered by relatively early stratification, characteristic of years with warm spring temperatures, which lowers P availability (Interlandi et al., 2003). We interpret the lake level to be at the height of the mid-lake shelf at this time. During the interval from 1390 to $890 \mathrm{cal} \mathrm{yr} \mathrm{BP,} \mathrm{both} \mathrm{water} \mathrm{depth} \mathrm{driven}$ by winter runoff and spring/summer stratification patterns likely are controls on diatom species composition, with decreases in water level/early stratification favoring C. stelligera (shallow, warm waters) dominated assemblages, whereas extended spring mixing (high P) and an increase in water depth leads to dominance of $S$. minutulus and/or A. formosa. From 890 to $44 \mathrm{cal} \mathrm{yr} \mathrm{BP,} \mathrm{the} \mathrm{increased}$ abundance of $S$. minutulus suggests that lake levels are sufficiently deep to support this species and that spring mixing is extensive, fostering the P-rich conditions necessary for this species to bloom. Frequent fluctuations in the abundance of benthic species suggest changes in water depth but indicate that the lake level has not decreased sufficiently to separate the two sub-basins.

Foy Lake has two distinct diatom assemblages in sediments spanning the last 2500 yr (Stevens et al., 2006; Stone and Fritz,
2006) (Figure 7). The period from 2650 to $1350 \mathrm{cal} \mathrm{yr} \mathrm{BP} \mathrm{is} \mathrm{dom-}$ inated by the benthic species Cymbella cymbiformis, Anomoeoneis costata, Encyonema silesiaca, and Craticula halophila, which suggest that lake levels were shallow and lower than present (Stevens et al., 2006). A. costata, a species that has a moderately high salinity tolerance growth optimum (Fritz et al., 1993), first appears at $2200 \mathrm{cal}$ yr BP, which suggests elevated salinity in the lake resulting from evaporative concentration (negative $\mathrm{P}-\mathrm{E}$ ), and thus very dry conditions. At several times between 1700 and 1400 cal yr BP, C. bodanica comprises approximately $40 \%$ of the assemblage for several decades. This planktonic, fresh-water species indicates short periods of increased moisture and higher lake levels within this overall dry period. C. bodanica dominates the diatom assemblage from 1350 to $600 \mathrm{cal} \mathrm{yr} \mathrm{BP,} \mathrm{which} \mathrm{suggests} \mathrm{lake-level} \mathrm{rise} \mathrm{as} \mathrm{a} \mathrm{result} \mathrm{of} \mathrm{a}$ continued increase in effective moisture. After $650 \mathrm{cal}$ yr BP, C. bodanica dominates, with several spikes of $C$. halophila, $(\sim 70,450$, and $650 \mathrm{cal} \mathrm{yr} \mathrm{BP)} \mathrm{suggesting} \mathrm{that} \mathrm{overall} \mathrm{lake} \mathrm{level} \mathrm{remains} \mathrm{high,} \mathrm{with}$ a few very short intervals of lowered lake level. A previous model integrating diatom and isotopic data suggests that the period after $\sim 650 \mathrm{cal}$ yr BP reflects the wettest conditions of the last $2600 \mathrm{yr}$ (Stevens et al., 2006).

\section{DCA results}

Ordination analysis provides a method to summarize the variability within the diatom species data. The lakes have large gradients of change in diatom species composition in multi-dimensional space, and the species do not exhibit a linear response; therefore, detrended correspondence analysis. (DCA) is the preferred ordination technique (ter Braak and Smilauer, 2002). Figure 8 shows the DCA results for all four lakes based on ordination 


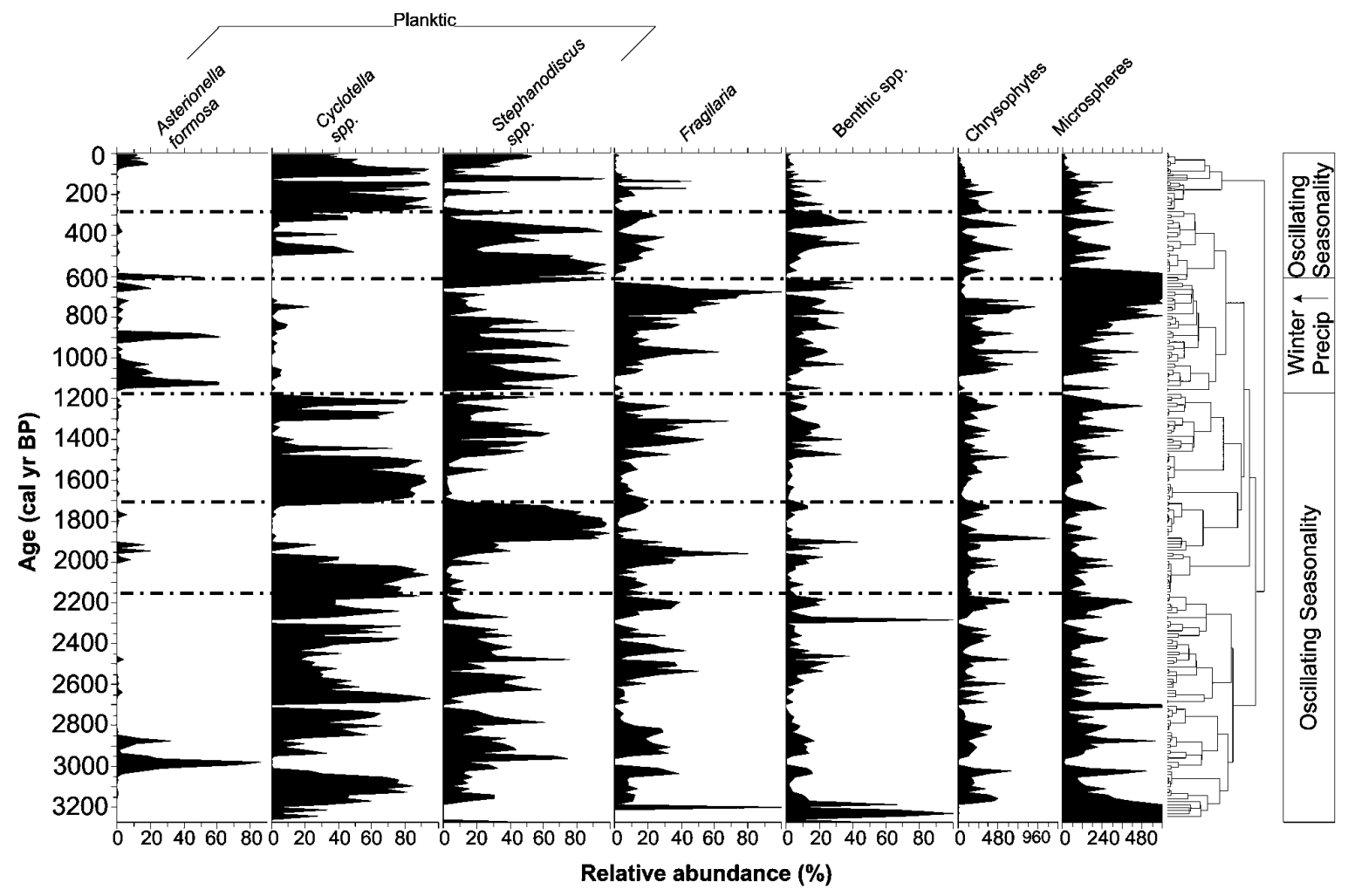

Figure 5. Morrison Lake diatom stratigraphy, cluster analysis and climatic interpretation. The dashed lines are zones identified by cluster analysis. A schematic interpretation of relative depth and temperature, as shown in other diatom figures, was not added to this figure, because the Morrison Lake record does not suggest strong directional precipitation or temperature shifts.

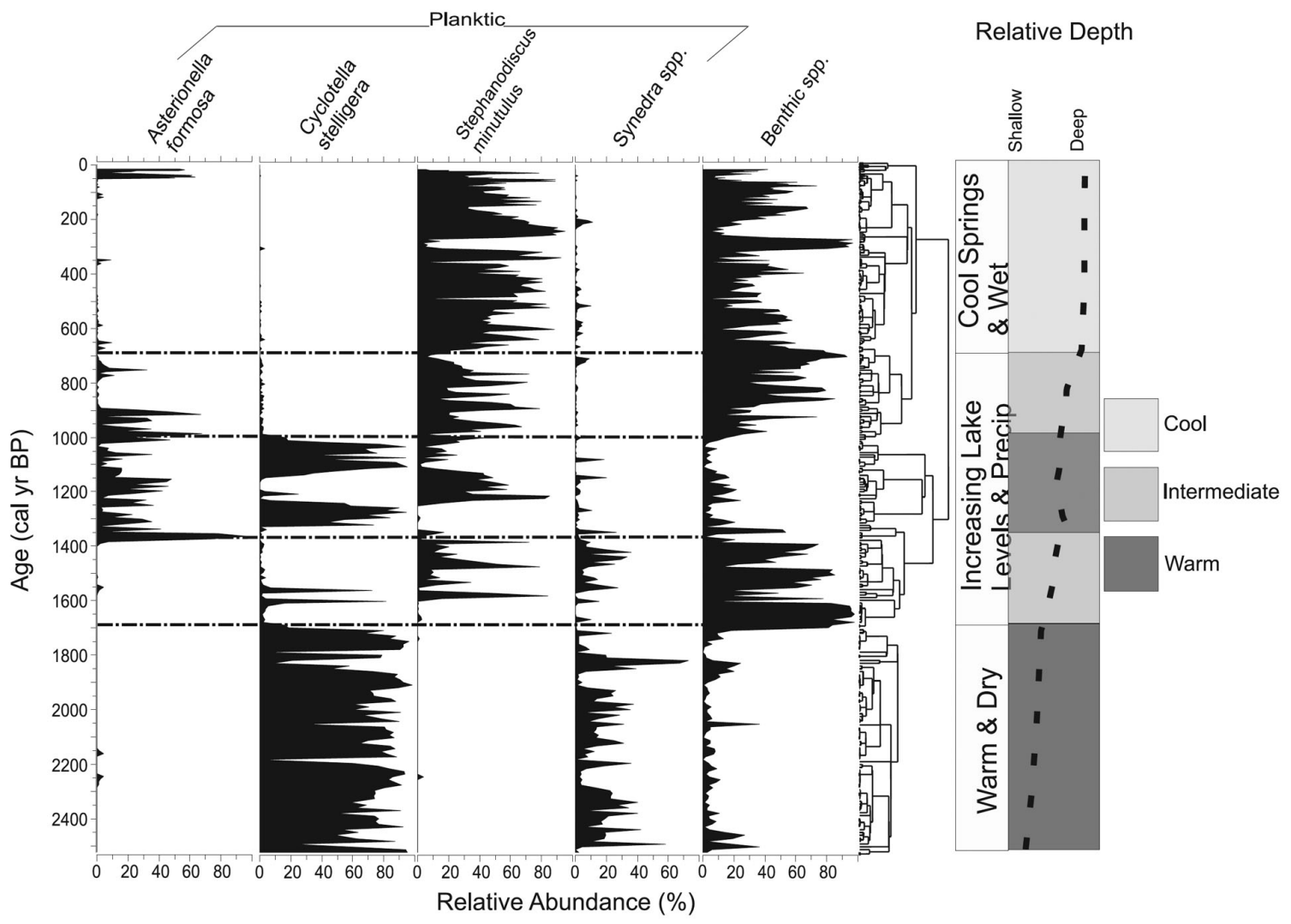

Figure 6. Reservoir Lake diatom stratigraphy, cluster analysis, and climatic interpretation. The schematic portion of the diagram shows a rough interpretation of the relative depth and relative temperature, based upon the diatoms. Stephanodiscus minutulus suggests cooler and deeper waters, whereas Cyclotella stelligera indicates slightly shallower and warmer conditions. 


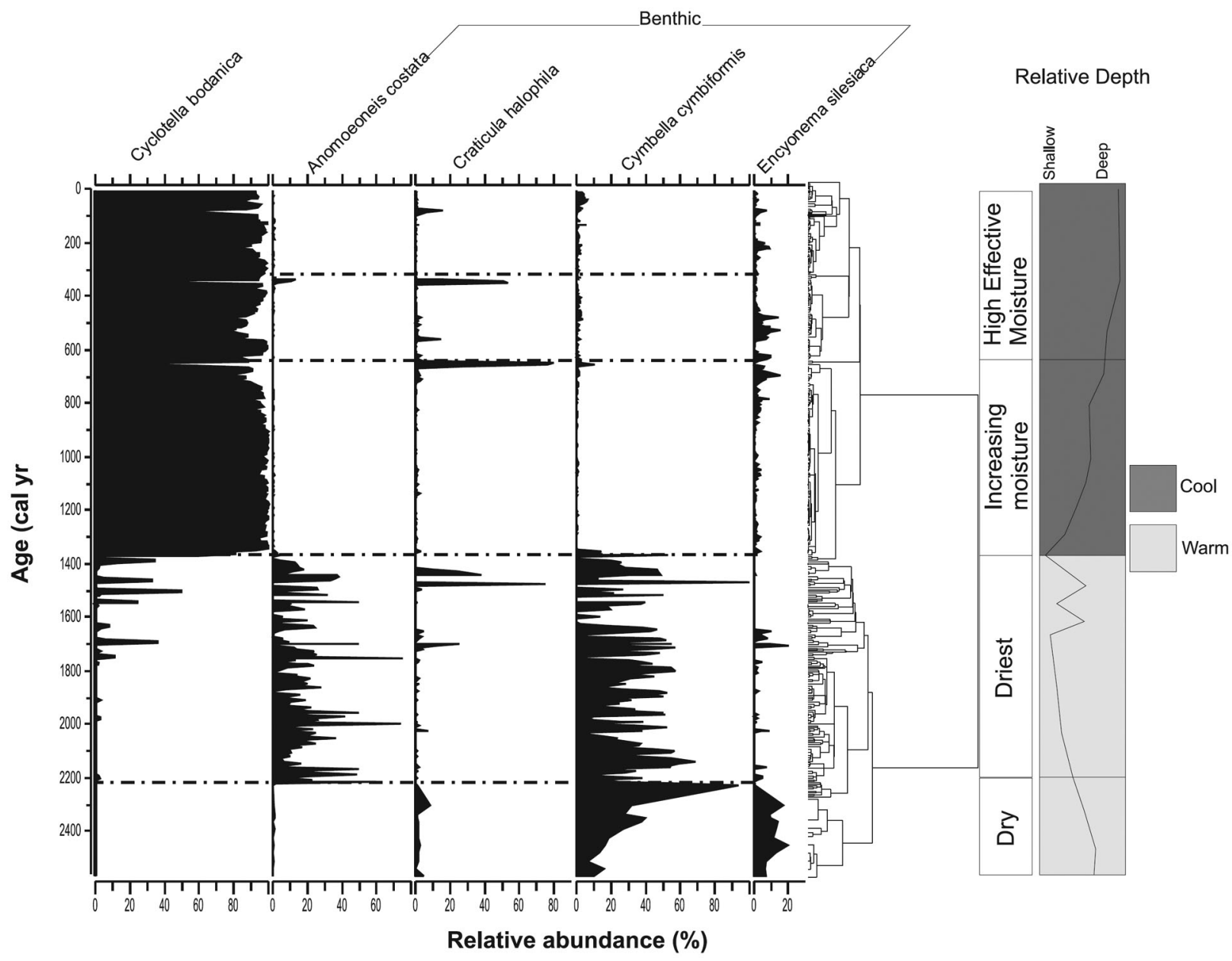

Figure 7. Foy Lake diatom stratigraphy, cluster analysis, and climatic interpretation. The dashed lines are zones identified by cluster analysis. The schematic portion of the diagram shows a qualitative interpretation of the relative depth and relative temperature, based upon the diatoms and previously published isotopic data (Stevens et al., 2006). After $1400 \mathrm{cal} \mathrm{yr} \mathrm{BP} \mathrm{Cyclotella} \mathrm{bodanica} \mathrm{dominates,} \mathrm{suggesting} \mathrm{a} \mathrm{transition} \mathrm{to} \mathrm{wetter,} \mathrm{cooler} \mathrm{conditions} \mathrm{than} \mathrm{from} 2500$ to $1400 \mathrm{cal} \mathrm{yr} \mathrm{BP.}$

of the species abundance data (> 5\%) in each core. The first axis scores are plotted for Crevice, Foy, and Reservoir lakes, while the third axis scores are plotted for Morrison Lake. For Crevice Lake, DCA1 is almost an exact replica of the $C$. bodanica curve. The first two axes of the Morrison Lake DCA did not show clear trends that could be related to diatom community structure, whereas DCA axis 3 mirrors relative diatom concentration/dissolution, which is a reflection of changes in the limnological environment. Reservoir Lake DCA1 seems to correspond to the $C$. stelligera curve for that lake. The Foy Lake DCA1 corresponds to the sum of the benthic species. Axis 1 explains $38.1 \%$ of the variance for Crevice Lake, $32.7 \%$ for Foy Lake, and 30.9\% for Reservoir Lake. For Morrison Lake, axes 1, 2, and 3 explain 17.8\%, 10.4\%, and $7.7 \%$ of the variance, respectively. The DCA axes adequately reflect patterns in the diatom zonation schemes as described previously and are used for spectral analysis.

\section{Spectral analysis results}

The MTM spectral analysis shows several dominant periodicities in each lake's diatom record (Figure 9). Crevice Lake shows dominant periodicities from 34 to $37 \mathrm{yr}$ and 52 to $58 \mathrm{yr}$. The dominant frequencies for Foy Lake are 32-36, 43, and 58-62 yr. Dominant periodicities in Morrison Lake data are 54-58 and 74-78 yr. Significant peaks also are present at $98,102,138$, and 151 yr. Reservoir Lake has significant periodicities at 37-42, 54-56, 81, and $250 \mathrm{yr}$.

\section{Discussion}

\section{Regional patterns}

Substantial shifts occur in diatom species composition in all four lakes throughout the past 2500 yr. Shifts that occur at similar times in all lakes include changes in the intervals from 2200 to $2100 \mathrm{cal} \mathrm{yr} \mathrm{BP,} 1700$ to $1600 \mathrm{cal} \mathrm{yr} \mathrm{BP,} 1350$ to $1200 \mathrm{cal} \mathrm{yr} \mathrm{BP,} \mathrm{and}$ 800 to 600 cal yr BP (Figure 10). All lakes show limnological change in these intervals, but the nature of change is not the same in all basins. The earliest common interval of change is defined by cluster analysis at 2100, 2150, 2200, and 2200 cal yr BP for Crevice, Morrison, Reservoir, and Foy lakes, respectively. During this interval, Crevice Lake switches from a $S$. minutulus and $S$. tenera to a $C$. bodanica dominated assemblage, suggesting a shortening of the spring season relative to the summer season. At this time in Foy Lake, A. costata first appears, which indicates particularly dry conditions within an extremely dry interval (Saros and Fritz, 2000). Morrison Lake shows a slow transition from Stephanodiscus to Cyclotella, which also suggests a seasonality change from long cool springs to long warm summers. Reservoir Lake shows severe dissolution within the diatom record during this time, which implies elevated alkalinity associated with significant decreases in effective moisture. Thus from 2200 to 2100 cal yr BP, Crevice and Morrison lakes show a change in seasonality to longer warm summers, while Foy and Reservoir lakes show evidence of significantly drier conditions, which could be a product of enhanced temperatures, decreased precipitation, or both. 


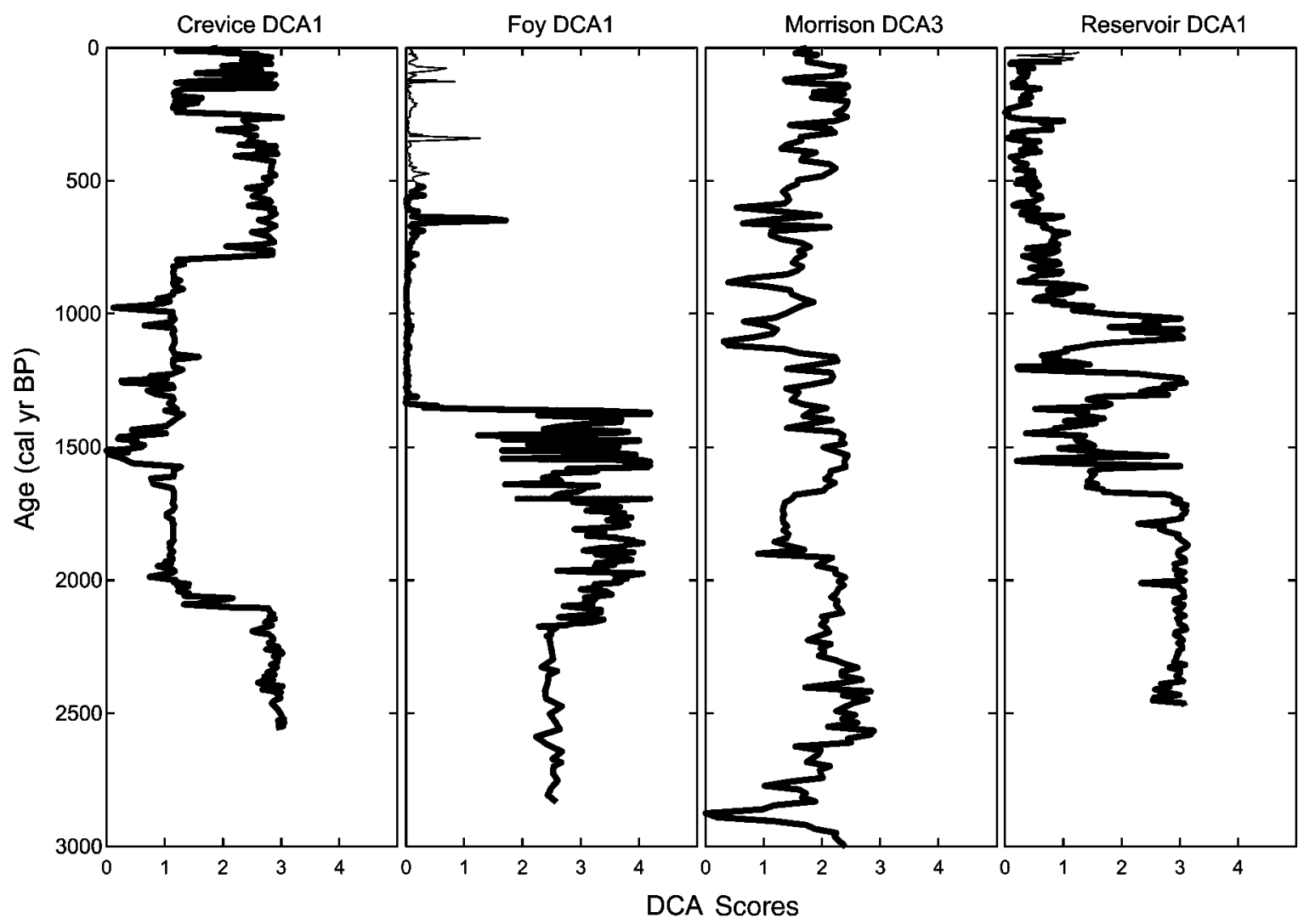

Figure 8. Detrended correspondence analysis (DCA) results. The first axis is plotted for Crevice Lake, Foy Lake, and Reservoir Lake, while the third axis is plotted for Morrison Lake. These data are used as inputs in the spectral analyses (see text).

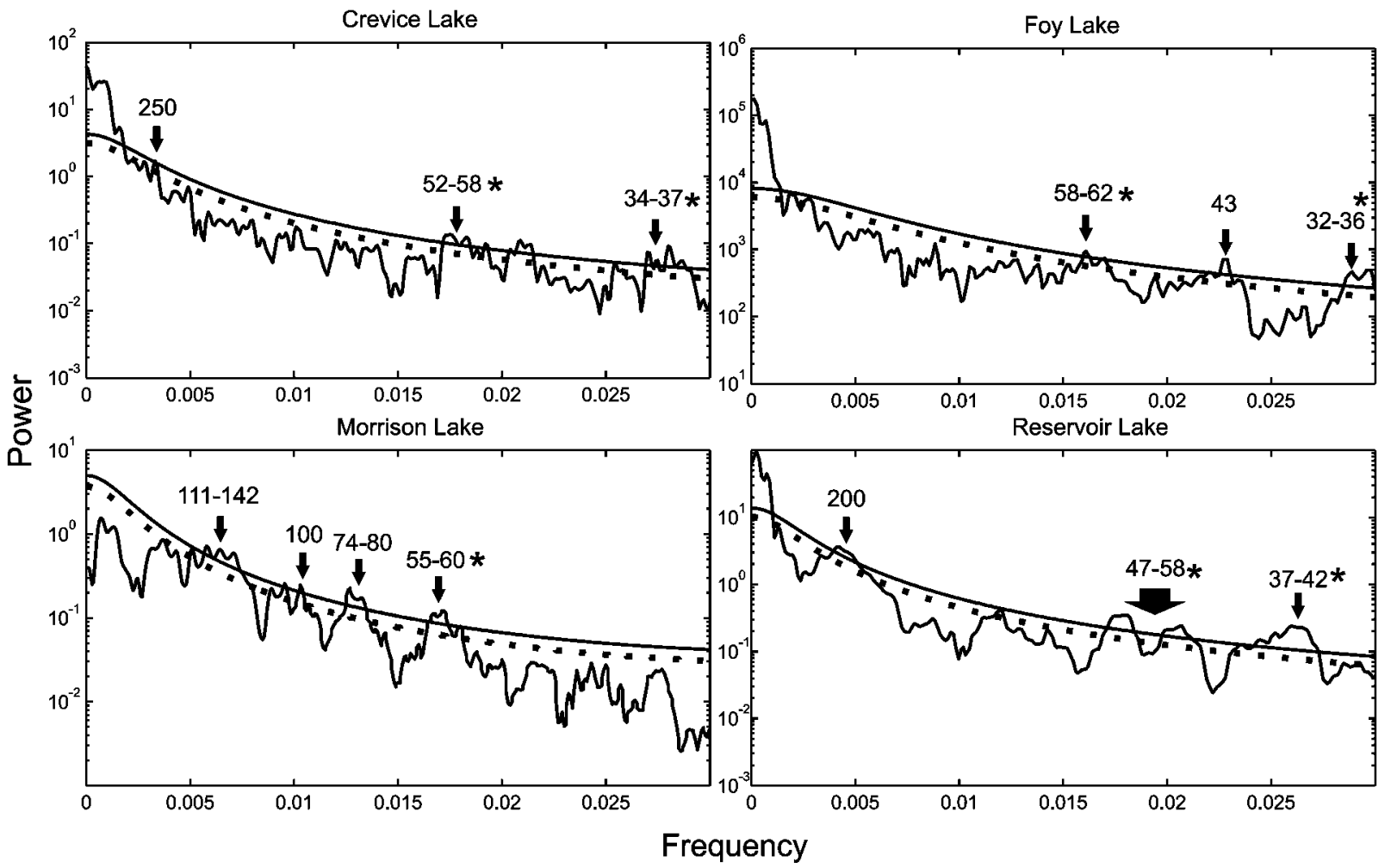

Figure 9. Spectral analysis results for each of the four lakes. Each subplot contains three lines: the spectral frequency, 95\%, and 99\% confidence lines. Only peaks above the $99 \%$ confidence line are considered significant in this analysis. The solid line and dotted line are the 99\% and 95\% confidence levels, respectively. Crevice Lake, Foy Lake, Morrison Lake, and Reservoir Lake show periodicities consistent with either the PDO or the AMO, as denoted with the asterisk $(*)$. See text for further information. 


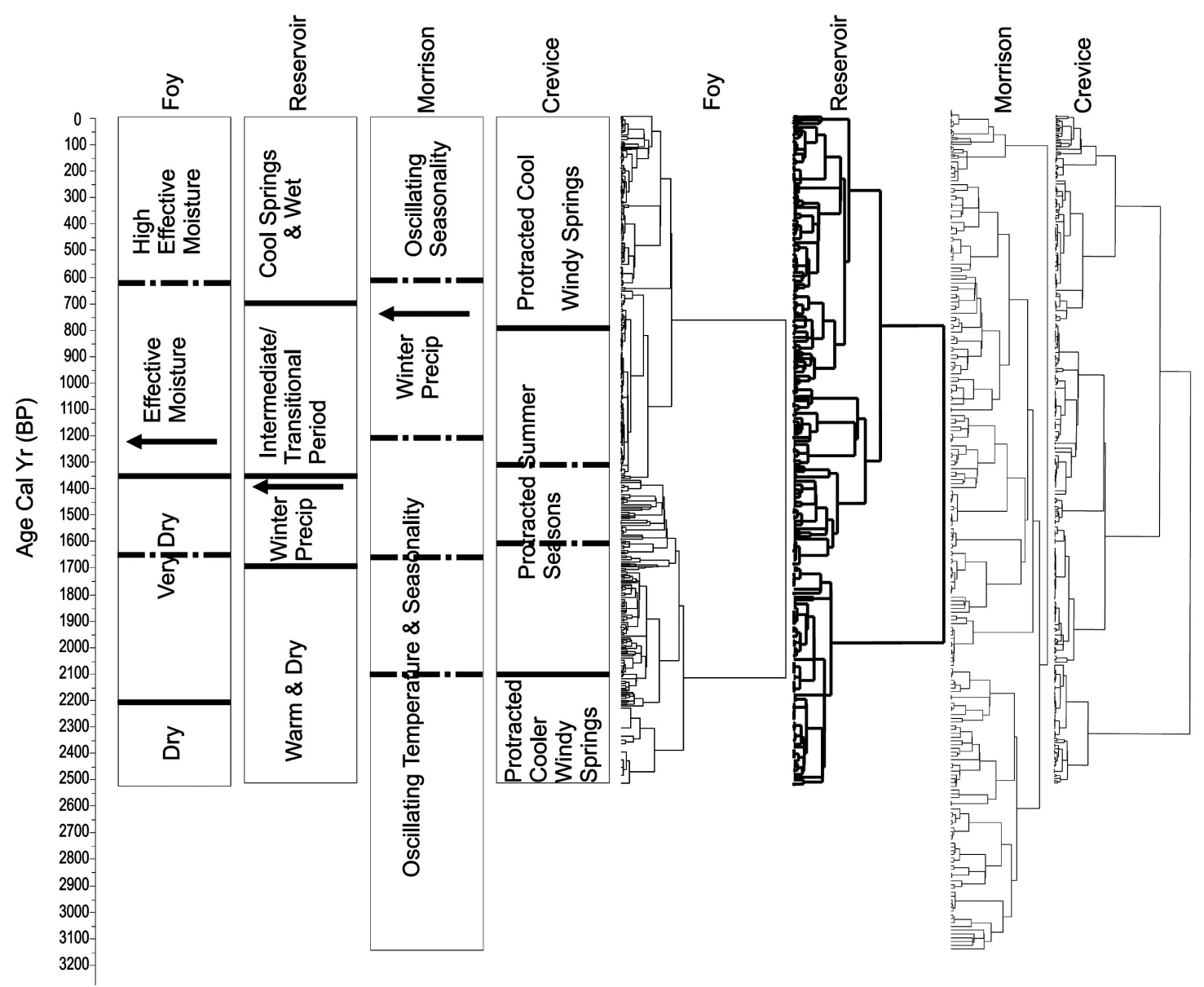

Figure 10. Schematic diagram showing the timing and nature of environmental changes in the four lakes, which show synchronous shifts in the intervals $2200-2100,1700-1600,1350-1200$, and 800-600 cal yr BP. In the left-hand portion of the figure the solid lines denote major changes in the composition of the diatom assemblage, indicative of distinct changes in climate. The dashed lines indicate smaller changes in species composition. All zones are derived from cluster analysis, as shown in the right hand portion of the figure. The environmental interpretations are derived from the known ecological characteristics of the diatom species as described in the text.

Limnological changes also occur in all lakes at approximately 1700-1600 cal yr BP. The shift in Morrison Lake from Stephanodiscus, which blooms during the spring mixing season, to Cyclotella, which blooms during summer stratification, is indicative of truncated spring mixing and more sustained summer stratification (Interlandi et al., 1999). In Crevice Lake the shift from C. bodanica to C. michiganiana results from a protracted summer season. Thus, the data indicate a climatic forcing that increased the length of the summer season in the regions surrounding Crevice and Morrison lakes. The interval from 1700 to $1600 \mathrm{cal} \mathrm{yr}$ BP shows an overall increase in lake level and inferred effective moisture for Reservoir Lake, whereas overall lake levels at Foy Lake are low, although the first appearance of C. bodanica in Foy Lake, at approximately $1700 \mathrm{cal} \mathrm{yr} \mathrm{BP,} \mathrm{indicates}$ short-lived periods of increased moisture and higher lake levels. The differences in climate response among the sites suggest either a sharp north to south climatic gradient, or more likely, differential sensitivity of the lakes to different aspects of climate, as a result of differences in morphometric or geochemical settings.

Between 1350 and $1200 \mathrm{cal}$ yr BP, all four lakes show a rapid change in diatom community structure. Crevice Lake shows a transition from $C$. michiganiana to $C$. bodanica, indicating a decrease in the duration of summer stratification or deeper mixing depths associated with summer cooling. Morrison Lake shows the sudden dominance of $A$. formosa, which implies an increase in winter precipitation and spring runoff. Foy Lake switches from a benthicdominated community to a planktic-dominated community, as manifested in by the abundance of $C$. bodanica. This indicates an in- crease in lake depth associated with increased effective moisture. The Reservoir Lake record shows the sudden dominance of $A$. formosa, most likely resulting from increased winter precipitation and spring runoff. Thus, overall the data suggest cooler springs that reduced the length of thermal stratification, along with increases in winter precipitation at Foy, Morrison, and Reservoir lakes.

The 800-600 cal yr BP change is a major shift in diatom species composition and corresponds with the transition from the Medieval Climate Anomaly (MCA) to the Little Ice Age. The shift in Crevice Lake, from a Cyclotella- to Stephanodiscus-dominated system, implies a marked change in temperature seasonality, from protracted summer seasons to short summer seasons (Interlandi et al., 1999). Morrison Lake shifts from an A. formosa-dominated assemblage to a Fragilaria- and Stephanodiscus-dominated system. This also suggests a change in seasonality, with shorter periods of summer stratification, possibly associated with a reduction in both winter precipitation and $\mathrm{N}$ inputs in runoff. In Reservoir Lake, the $890 \mathrm{cal}$ yr BP shift from $C$. stelligera and A. formosa to $S$. minutulus and other benthic species suggests that the lake remained moderately deep, in addition to shorter periods of summer stratification. Foy Lake shows a spike of $C$. halophila at approximately $625 \mathrm{cal} \mathrm{yr} \mathrm{BP.} \mathrm{Stevens} \mathrm{et} \mathrm{al.}$ (2006) interpret this benthic spike as a modest rise in lake level. Thus, Crevice, Morrison, and Reservoir lakes show evidence of a transition to protracted cool springs and shorter summers, while Foy Lake shows a moderate increase in effective moisture, which similarly could be a product of lower spring and summer temperatures or could reflect an increase in precipitation. 
Crevice and Morrison lakes also show similarities in the nature and timing of their diatom stratigraphies during the last $600 \mathrm{yr}$. At approximately $250 \mathrm{cal}$ yr BP, both Crevice and Morrison lakes switch from a Stephanodiscus- to a Cyclotella-dominated assemblage. Cyclotella dominates for $100 \mathrm{yr}$ at Crevice Lake and $150 \mathrm{yr}$ at Morrison Lake. This shift likely represents the culmination of the regional Little Ice Age and climatic warming in spring and summer. After this, both lakes show frequent alternations between Stephanodiscus and Cyclotella.

\section{Forcing of regional climate change}

The similarities in the timing of change among the four lakes suggest that regional-scale climatic change is largely responsible for the major changes in diatom community structure. Potential largescale mechanisms that might produce these climatic variations include solar variations and/or sea-surface temperature anomalies that affect jet-stream position and circulation patterns, and/or the strength of the westerlies (Williams et al., 1996; Feng et al., 2008). Most of these mechanisms are interrelated variations in the expression of large-scale atmospheric circulation patterns across North America. Sea-surface temperature (SST) changes in both the Pacific and Atlantic oceans are associated with variations in temperature and precipitation in the Rocky Mountains (McCabe et al., 2004).

The spectral analysis suggests a number of common frequencies of variation among the lakes. The most common frequency or set of frequencies for all four lakes is 50-62 yr (Figure 9), a frequency that is commonly associated with the Pacific Decadal Oscillation (PDO) (Mantua et al., 1997; Mantua and Hare, 2002). In Crevice, Foy, and Reservoir lakes, significant variability also occurs in the 34-42 yr band, which is a recurrent periodicity associated with the Atlantic Multi-decadal Oscillation (AMO) (Knight et al., 2006). Many studies suggest that Atlantic SST anomalies are highly correlated with the spatial patterns of North American drought (McCabe et al., 2004; Sutton and Hodson, 2005). Feng et al. (2008) propose that warm Pacific SST anomalies intensified drought in the northern Great Plains during MCA, while cool Atlantic SST anomalies extended the size of the afflicted region. Other research connects paleodroughts in the Rocky Mountain region with frequencies characteristic of the PDO (Stone and Fritz, 2006; Tian et al., 2006). The correlation of Rocky Mountain lake behavior with periodicities evident in both Pacific and Atlantic SST records suggests that both oceans are instrumental in influencing long-term North American climate variation (McCabe et al., 2008).

Changes in overall atmospheric circulation are manifested in the location and/or strength of high/low pressure centers, which can cause displacement of the jet stream (Oglesby and Erickson, 1989; Laird et al., 2003; Booth et al., 2006a). In the Rocky Mountain region studied here, the polar jet stream commonly moves across the region during winter and spring. One hypothesis is that jet stream placement may explain different hydrologic signals between northern and southern sites, such as apparent dry conditions at Foy Lake prior to $1700 \mathrm{cal} \mathrm{yr} \mathrm{BP}$ and elevated winter precipitation at lakes further south. Crevice Lake and possibly Morrison Lake receive significant summer precipitation from the Gulf of Mexico at present (Figure 1) (Whitlock et al., 2008), whereas the other lakes do not, and these differences in the seasonality of precipitation may produce different sensitivities of individual sites to seasonal aspects of climate variability. Strength of the summer westerlies also has been associated with drought in the Northern Rockies and Great Plains regions (Booth et al., 2006a), and has been invoked as a forcing for the western megadrought that occurred in western North America during the MCA (Bryson, 1966; Booth et al., 2006b). Sridhar et al. (2006) suggest an inter-related mechanism in which a change in wind direction reduced the precipitation supply from the Gulf Coast to the High Plains, resulting in severe drought during the MCA. While this study region is considerably west of the High Plains, precipitation from the Gulf does reach some portions of Montana, including the northern range of Yellowstone (Whitlock and Bartlein, 1993).

\section{Conclusion}

Throughout the previous $2500 \mathrm{yr}$, the western Montana lakes studied here have undergone significant shifts in diatom community structure. The lakes show synchronous changes in diatom stratigraphy at several separate intervals: 2200-2100, 1700-1600, $1350-1200,800-600$, and $250 \mathrm{cal}$ yr BP, which suggest that the limnological changes reflect changes in large-scale climatic forcing. There is also evidence in several sites for limnological change at 300-250 cal yr BP. Many of the shifts in the diatom assemblages span just a few decades, which may indicate that the climatic transitions were abrupt. The diatom records at different sites and at different times reflect different aspects of climate. Crevice Lake and Morrison Lake reflect changes in the duration of spring mixing relative to summer stratification, which suggests that these two basins are most sensitive to changes in the lake's energy balance and its seasonality. In contrast, the diatom changes in Foy Lake and Reservoir Lake reflect changes in lake level, suggesting that these lakes respond most strongly to changes in the regional hydrologic budget, likely because the basin morphometry dictates that lake-level change produces large variation in habitat availability for shallowwater benthic diatoms (Stone and Fritz, 2004). The seasonality of precipitation of Foy and Reservoir lakes also may differ from the other two sites, and it may be that these two lakes were more sensitive to variations in precipitation within a certain season, such as changes in winter snowpack and associated spring runoff. Despite these differences in the nature of limnological changes, their coherent timing indicates that networks of lake sites can be used in montane regions to reconstruct regional climate variation operating at multi-decadal to centennial scales.

Acknowledgments - We would like to thank the editor, Wyatt Oswald, and the anonymous reviewers for Quaternary Research, whose comments greatly improved this manuscript. Eric Grimm obtained the cores from Morrison and Reservoir lakes and the radiocarbon dates for these sites. C. Whitlock, W. Dean, J. Stone, L. Stevens, M. Power, J. Campbell, J. Rosenbaum, K. Pierce, L. Doner, J. Honke, and G. Skipp assisted with coring Crevice and Foy lakes. Funds from NSF (EAR-0816576, EAR9905262), Yellowstone National Park, and the USGS supported this research. We would also like to thank Jeffrey Stone and Karlyn Westover for their comments and suggestions. Pat Bartlein designed and produced the data analysis used in Figure 1B.

\section{References}

Barry, R., 1990. Changes in mountain climate and glacio-hydrological responses. Mountain Research and Development 10, 161-170.

Barry, R., 1992. Mountain climatology and past and potential future climatic changes in mountain regions: A review. Mountain Research and Development 12, 71-86.

Battarbee, R., Kneen, M., 1982. The use of electronically counted microspheres in absolute diatom analysis. Limnology and Oceanography 27, 184-188.

Bennett, K., 1996. Determination of the number of zones in a biostratigraphical sequence. New Phytologist 132, 155-170.

Booth, R.K., Kutzbach, J.E., Hotchkiss, S.C., Bryson, R.A., 2006a. A reanalysis of the relationship between strong westerlies and precipitation in the Great Plains and Midwest regions of North America. Climatic Change 76, 427-441.

Booth, R.K., Notaro, M., Jackson, S., Kutzbach, J., 2006b. Widespread drought episodes in the western Great Lakes region during the past 2000 years: Geographic extent and potential mechanisms. Earth and Planetary Science Letters 242, 415-427.

Bracht, B., Stone, J.R., Fritz, S.C., 2008. A diatom record of late Holocene climate variation in the northern range of Yellowstone National Park, USA. Quaternary International 188, 149-155. 
Bradbury, J., 1988. A climatic-limnologic model of diatom succession for paleolimnological interpretation of varved sediments at Elk Lake, Minnesota. Journal of Paleolimnology 1, 115-131.

Briffa, K., Osborn, T., Schweingruber, F., Harris, I., Jones, P., Shiyatov, S., Vaganov, E., 2001. Low-frequency temperature variations from a northern tree ring density network. Journal of Geophysical Research 106, 2929-2941.

Bryson, R., 1966. Air masses, streamlines, and the boreal forest. Geographical Bulletin 8, 228-269.

Buntgen, U., Esper, J., Frank, D., Nicolussi, K., Schmidhalter, M., 2005. A 1052-year tree-ring proxy for alpine summer temperatures. Climate Dynamics 25, 141-153.

Cook, E., Seager, R., Cane, M., Stahle, D., 2007. North American drought: Reconstructions, causes, and consequences. Earth-Science Reviews 81, 93-134.

Feng, S., Oglesby, R., Rowe, C., Loope, D., Hu, Q., 2008. Atlantic and Pacific SST influences on Medieval drought in North America simulated by the Community Atmospheric Model. Journal of Geophysical Research 113, D11101.

Fritz, S.C., Juggins, S., Battarbee, R., 1993. Diatom assemblages and ionic characterization of lakes of the northern Great Plains, North America: A tool for reconstructing past salinity and climate fluctuations. Canadian Journal of Fisheries and Aquatic Sciences 50, 1844-1856.

Gage, J., 2008. Forest disturbance history in the Sawtooth Mountains of central Idaho and the Beaverhead range of western Montana. Master's thesis. Montana State University.

Ghil, M., Allen, M., Dettinger, M., Ide, K., Kondrashov, D., Mann, M., Robertson, A., Saunders, A., Tian, Y., Varadi, F., 2002. Advanced spectral methods for climatic time series. Reviews of Geophysics 40, 3.1-3.41.

Gray, S., Graumlich, L., Betancourt, J., Pederson, 2004. A tree-ring based reconstruction of the Atlantic Multidecadal Oscillation since 1567 AD. Geophysical Research Letters 31, L12205.

Gray, S., Graumlich, L., Betancourt, J., 2007. Annual precipitation in the Yellowstone National Park region since AD 1173. Quaternary Research 68, 18-27.

Grimm, E., 1987. Coniss: a Fortran 77 program for stratigraphically constrained cluster analysis by the method of incremental sum of squares. Computers and Geosciences 13, 13-35.

Higuera, P., Peters, M., Brubaker, L., Gavin, D., 2007. Understanding the origin and analysis of sediment-charcoal records with a simulation model. Quaternary Science Reviews 26, 1790-1809.

Interlandi, S.J., Kilham, S., Theriot, E., 1999. Responses of phytoplankton to varied resource availability in large lakes of the Greater Yellowstone ecosystem. Limnology and Oceanography 44, 668-682.

Interlandi, S., Kilham, S., Theriot, E., 2003. Diatom-chemistry relationships in Yellowstone Lake (Wyoming) sediments: implications for climatic and aquatic processes research. Limnology and Oceanography 48, 79-92.

Kilham, S., Theriot, E., Fritz, S.C., 1996. Linking planktonic diatoms and climate change in the large lakes of the Yellowstone ecosystem using resource theory. Limnology and Oceanography 41, 1052-1062.

Knight, J., Folland, C., Scaife, A., 2006. Climate impacts of the Atlantic Multidecadal Oscillation. Geophysical Research Letters 33, L17706.

Laird, K., Cumming, B., Wunsam, S., Rusak, J., Oglesby, R., Fritz, S.C., Leavitt, P., 2003. Lake sediments record large-scale shifts in moisture regimes across the northern prairies of North America during the past two millennia. Proceedings of the National Academy of Sciences 100, 2483-2488.

Mantua, N., Hare, S., 2002. The Pacific decadal oscillation. Journal of Oceanography $58,35-44$.

Mantua, N., Hare, S., Zhang, Y., Wallace, J., Francis, R., 1997. A Pacific interdecadal climate oscillation with impacts on salmon production. Bulletin of the American Meteorological Society 78, 1069-1070.

McCabe, G.J., Palecki, M., Betancourt, J., 2004. Pacific and Atlantic Ocean influences on multidecadal drought frequency in the United States. Proceedings of the National Academy of Sciences 101, 4136-4141.

McCabe, G.J., Betancourt, J., Gray, S., Palecki, M., Hidalgo, H., 2008. Associations of multi-decadal sea-surface temperature variability with US drought. Quaternary International 188, 31-40.
Mock, C., 1996. Climatic controls and spatial variations of precipitation in the western United States. Journal of Climate 9, 1111-1125.

Morabito, G., Ruggiu, D., Panzani, P., 2001. Trends of phytoplankton characteristics and their communities in pre-and post-liming time in Lake Orta (1984-1998). Journal of Limnology 60, 91-100.

Oglesby, R., Erickson III, D., 1989. Soil moisture and the persistence of North American drought. Journal of Climate 2, 1362-1380.

Paillard, D., Labeyrie, L., Yiou, P., 1996. Macintosh program performs timeseries analysis. Eos 77, 379.

Power, M., Whitlock, C., Bartlein, P., Stevens, L., 2006. Fire and vegetation history during the last 3800 years in northwestern Montana. Geomorphology $75,420-436$.

Ruhland, K., Priesnitz, A., Smol, J., 2003. Paleolimnological evidence from diatoms for recent environmental changes in 50 lakes across Canadian Arctic treeline. Arctic, Antarctic, and Alpine Research 35, 110-123.

Salzer, M.W., Kipfmueller, K.F., 2005. Reconstructed temperature and precipitation on a millennial timescale from tree-rings in the southern Colorado Plateau, USA. Climatic Change 70, 465-487.

Saros, J., Fritz, S., 2000. Changes in the growth rates of saline-lake diatoms in response to variation in salinity, brine type and nitrogen form. Journal of Plankton Research 22, 1071-1083.

Saros, J., Michel, T., Interlandi, S., Wolfe, A., 2005. Resource requirements of Asterionella formosa and Fragilaria crotonensis in oligotrophic alpine lakes: Implications for recent phytoplankton community reorganizations. Canadian Journal of Fisheries and Aquatic Sciences 62, 1681-1689.

Schmidt, R., Psenner, R., Muller, J., Indinger, P., 2002. Impact of late glacial climate variations on stratification and trophic state of the meromictic Lake Langsee (Austria): Validation of a conceptual model by multi proxy studies. Journal of Limnology 61, 49-60.

Sridhar, V., Loope, D., Swinehart, J., Oglesby, J.M.R., Rowe, C., 2006. Large wind shift on the Great Plains during the Medieval Warm Period. Science 313, 345-347.

Stevens, L., Stone, J.R., Campbell, J., Fritz, S.C., 2006. A 2200-yr record of hydrologic variability from Foy Lake, Montana, USA, inferred from diatom and geochemical data. Quaternary Research 65, 264-274.

Stone, J.R., Fritz, S.C., 2004. Three-dimensional modeling of lacustrine diatom habitat areas: Improving paleolimnologic interpretation of planktic:benthic ratios. Limnology and Oceanography 49, 1540-1548.

Stone, J.R., Fritz, S.C., 2006. Multidecadal drought and Holocene climate instability in the Rocky Mountains. Geology 34, 409-412.

Stuvier, M., Reimer, P., Bard, E., 1993. Intcal98 radiocarbon age calibration 24,000-0 cal BP. Radiocarbon 40, 1041-1083.

Sutton, R., Hodson, D., 2005. Atlantic Ocean forcing of North American and European summer climate. Science 309, 115-117.

ter Braak, C., Smilauer, P., 2002. CANOCO Reference Manual and CanoDraw for Windows Users' Guide: Software for Canonical Community Ordination (version 4.5). Microcomputer Power. Ithaca, NY, USA.

Theriot, E., Fritz, S., Gresswell, R., 1997. Long-term limnological data from the larger lakes of Yellowstone National Park, Wyoming, U.S.A. Arctic and Alpine Research 29, 304-314.

Tian, J., Nelson, D., Hu, F., 2006. Possible linkages of late-Holocene drought in the North American midcontinent to Pacific Decadal Oscillation and solar activity. Geophysical Research Letters 33, L23702.

Tilman, D., Kilham, S., Kilham, P., 1982. Phytoplankton community ecology: The role of limiting nutrients. Annual Reviews in Ecology and Systematics 13, 349-372.

Whitlock, C., Bartlein, P., 1993. Spatial variations of Holocene climatic change in the Yellowstone region. Quaternary Research 39, 231-238.

Whitlock, C., Dean, W.R.J., Stevens, L., Fritz, S., Bracht, B., Power, M., 2008 A 2650-year-long record of environmental change from northern Yellowstone National Park based on a comparison of multiple proxy data. Quaternary International 188, 126-138.

Williams, M., Losleben, M., Caine, N., Greenland, D., 1996. Changes in climate and hydrochemical responses in a high-elevation catchment in the Rocky Mountains, USA. Limnology and Oceanography 41, 939-946.

Wolfe, A.P., Gorp, A.V., Baron, J., 2003. Recent ecological and biogeochemical changes in alpine lakes of Rocky Mountain National Park (Colorado, USA): A response to anthropogenic nitrogen deposition. Geobiology 1, 153-168. 